\title{
A Randomized Case-controlled Clinical Trial of the Effect of Preemptive Etoricoxib, Prednisolone and a Control Group on of Postoperative Sequelae after Surgical Removal of Impacted Mandibular Third Molars
}

\author{
Hasanin A. Mubarak ${ }^{1}$, Sahar S. Al-Adily ${ }^{2}$ \\ ${ }^{1}$ Master Student, Department of Oral and Maxillofacial Surgery, College of Dentistry-University of Baghdad, \\ ${ }^{2}$ Assistant Professor, Department of Oral and Maxillofacial Surgery, College of Dentistry-University of Baghdad
}

\begin{abstract}
Background: The aim of this study was to compare the anti-inflammatory effects of prednisolone and etoricoxib after third molar extraction.

Method: A prospective, controlled study was conducted on 39 volunteers were allocated in three different groups, to receive either $120 \mathrm{mg}$ etoricoxib or 10mg prednisolone 30 minutes prior to the procedure, and also a controlled group who didn't receive any medication pre-operatively.Baseline measurements were obtained preoperatively, and subsequent assessments were made on immediate postoperative, at 48 hours and 7 days after surgery to measure postoperative facial swelling by use of linear measurements, interincisal mouth opening width and visual analog scale score for pain. The amount of analgesics consumed was recorded. Descriptive statistics were used to compare the two groups at $P<0.05$.

Conclusion: Considering the results that were obtained upon the efficacy of different pre-emptive medication, Etoricoxib showed statistically significant values in terms of pain reduction and restriction in mouth opening, in the other hand prednisolone showed significance results in terms of edema reduction.
\end{abstract}

Keywords: Corticosteroids, COX-2 selective, third-molar surgery.

\section{Introduction}

Removal of impacted third molars is a common procedure in the field of oral and maxillofacial surgery (1). The most important step in removal of impacted mandibular third molars is achieving an appropriate mucoperiosteal flap that provides enough access to the tooth. An envelope flap with or without releasing is the common flap design ${ }^{(2)}$.

Pain generated following third molar surgery has got short duration and moderate intensity that peaks in

\section{Corresponding Author:}

Hasanin A. Mubarak

Master Student, Department of Oral and Maxillofacial

Surgery, College of dentistry- University of Baghdad

e-mail: hasanin.mubarak@gmail.com short time after the procedure and drives the patients into taking some analgesic medications ${ }^{(3)}$.

Limitation of mouth opening is one of the problems which occurs following this surgery; this could be related to the inflammation of masticatory muscles. The medial pterygoid muscle is usually involved because of being inadvertently penetrated by the needle during inferior alveolar nerve block injection. This complication is not often severe and it will improve in 10-14 days ${ }^{(4)}$.

Glucocorticoid agents and NSAIDs are generally used in managing some post-operation difficulties. Inhibiting the cyclooxygenase path is the mechanism of action of NSAIDS while glucocorticoids restrain production of acid arachidonic by inhibiting the phospholipase A2 enzyme ${ }^{(5)}$. COX-2 is considered as the main isoenzyme in producing pro-inflammatory prostaglandins ${ }^{(3)}$. Although some side effects such 
as cardiovascular risks, GI bleeding and acute renal failure should be kept in mind ${ }^{(6)}$, some recent studies showed that there is no relationship between celecoxib consumption and mentioned risks ${ }^{(7,8)}$. The aim of this study was to compare the efficacy of prednisolone with celecoxib on maximum mouth opening (MMO) and pain relief following impacted mandibular third molar surgery.

\section{Materials and Method}

Subject: Patients requiring surgical removal of impacted $3^{\text {rd }}$ molar.

Materials: Etoricoxib120 mg preoperatively on group 1.

Prenidisolone $10 \mathrm{mg}$ preoperatively on group 2.

No medication preoperatively on group 3 .

All 3 groups were subjected to take the following tablets postoperatively:paracetamol $500 \mathrm{mg}$ on need, Augmentin $1000 \mathrm{mg}$ bid and Metraniadazole $500 \mathrm{mg}$ tid.

Sample Size: 39 patients aged between 18-40 years.

Procedure/Intervention: The medications were given 30 minutes before the procedure on each group. follow up was conducted on 48 hours, and 1 week to check for the criteria of interincisal mouth opening distance by using a digital caliper, pain by using visual analog scale, and 2 lines to record inflammation : the first line is the distance from corner of mouth to attachment of ear lobe and the second line is the distance from outer canthus of eye to angle of mandible.

Removal of the desired tooth according to Pell and Gregory classification wasrecorded. And all the procedures will be conducted by same surgeon. Patients were distributed into 3 groups of 13 patients each and received either etoricoxib, prednisolone or no medication group.

Time was calculated on all procedures assist difficulty.

All surgical flaps were conventional ones with a releasing flap in the mesial side of second molar and then sutured by silk $3-0$.

Timetable: One year started from February 2020 until the end of July 2020.

\section{Results}

Note: patients were allocated on 3 groups Etoricoxib group (group A), Prednisolone group (group B) and placebo control group (group C).

\section{Age and Gender:}

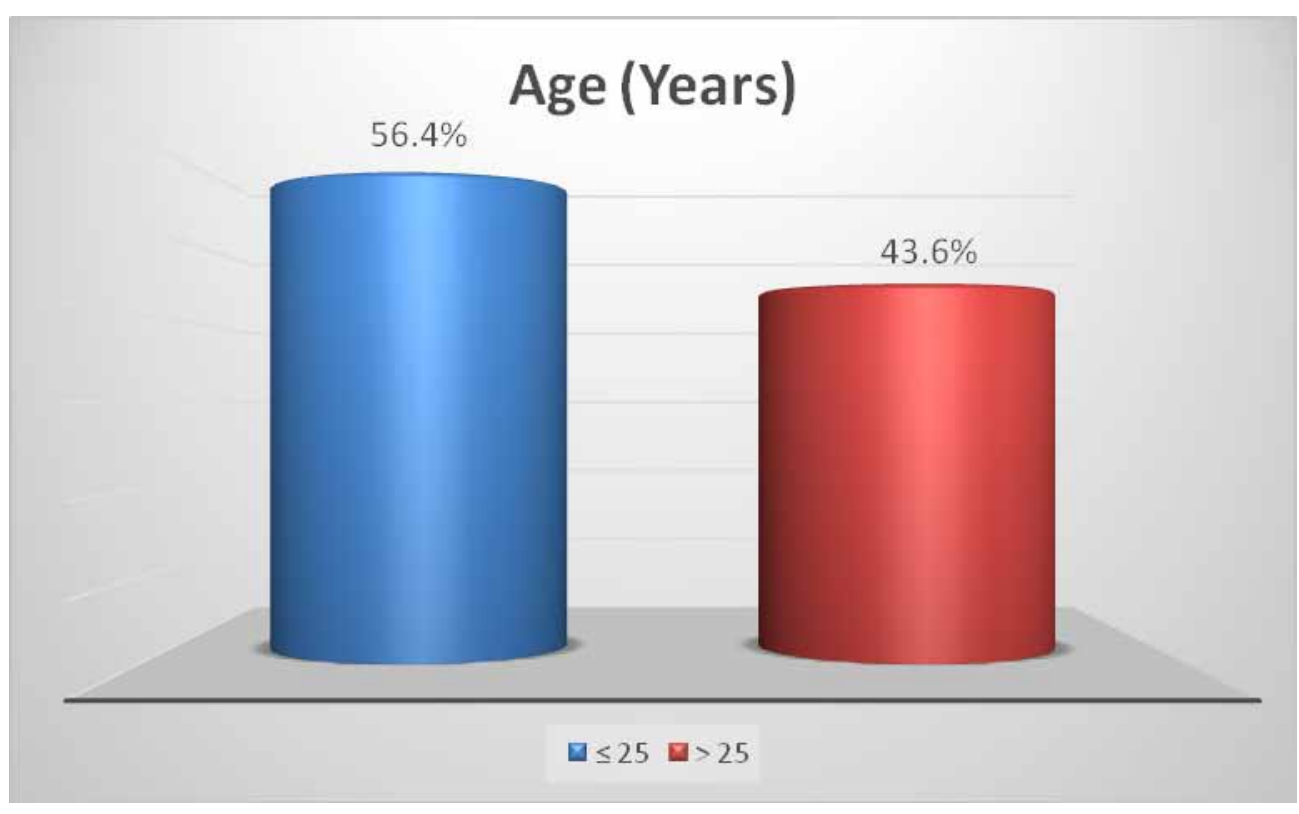

Figure 1: Distribution of study patients by age 


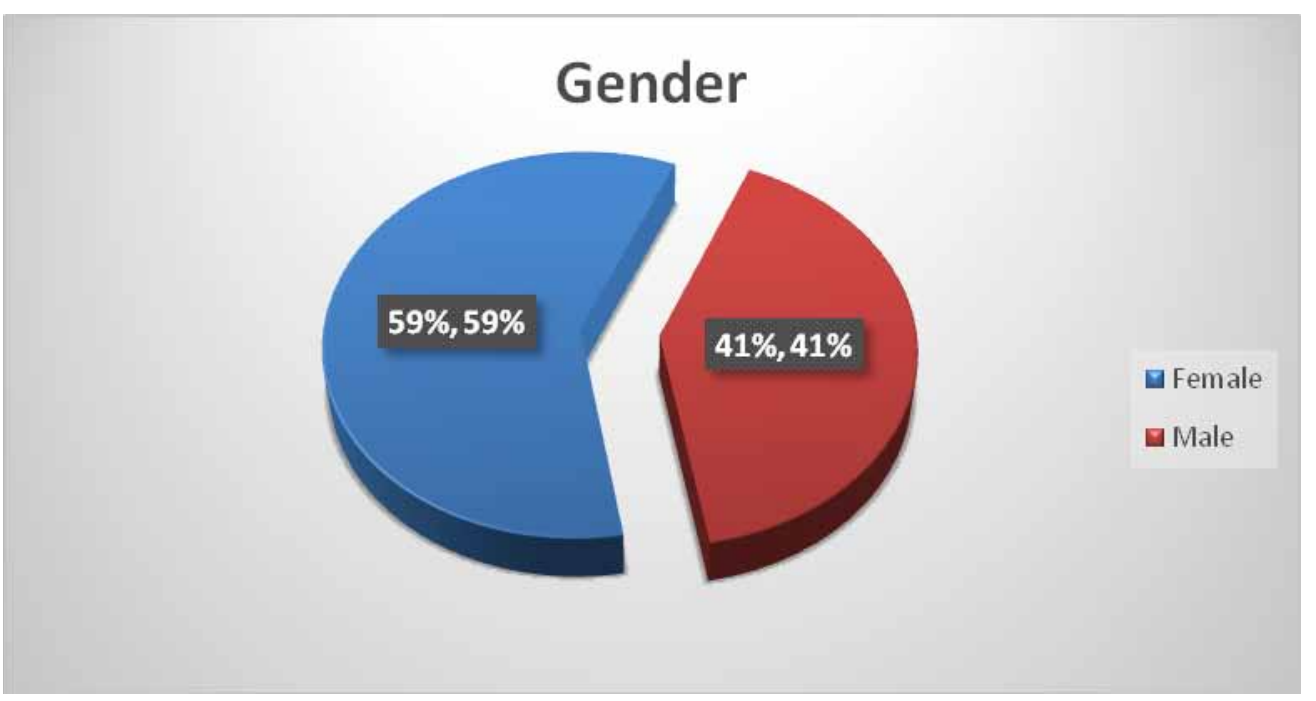

Figure 2: Distribution of study patients by gender

In comparison between study groups by age and gender, we found that there were no significant differences in age $(\mathrm{P}=0.495)$ and gender $(\mathrm{P}=0.899)$ between the groups.

Table 1: Comparison between study groups by age

\begin{tabular}{|l|c|c|c|c|c|}
\hline \multirow{4}{*}{ Age (Years) } & \multicolumn{3}{|c|}{ Study Groups } & \multirow{2}{*}{ F } & \multirow{2}{*}{ P- Value } \\
\cline { 2 - 6 } & $\begin{array}{c}\text { Group A } \\
\text { Mean } \pm \text { SD }\end{array}$ & $\begin{array}{c}\text { Group B } \\
\text { Mean } \pm \text { SD }\end{array}$ & $\begin{array}{c}\text { Group C } \\
\text { Mean } \pm \text { SD }\end{array}$ & & \\
\cline { 2 - 6 } & $26.1 \pm 4.69$ & $24.69 \pm 4.42$ & $24.1 \pm 3.80$ & 0.718 & 0.495 \\
\hline
\end{tabular}

Table 2: Comparison between study groups by gender

\begin{tabular}{|l|c|c|c|c|c|c|}
\hline \multirow{3}{*}{ Gender } & \multicolumn{3}{|c|}{ Study Group } & \multirow{2}{*}{ Total (\%) } \\
\cline { 2 - 4 } & $\begin{array}{c}\text { Group A } \\
\mathbf{n = 1 3}\end{array}$ & $\begin{array}{c}\text { Group B } \\
\mathbf{n = 1 3}\end{array}$ & $\begin{array}{c}\text { Group C } \\
\mathbf{n}=\mathbf{1 3}\end{array}$ & \multirow{2}{*}{$\mathbf{X}^{\mathbf{2}}$} & \multirow{2}{*}{ P-Value } \\
\cline { 1 - 4 } Male & $6(37.4)$ & $5(31.3)$ & $5(31.3)$ & $16(41.0)$ & 0.302 & 0.899 \\
\hline Female & $7(30.4)$ & $8(34.8)$ & $8(34.8)$ & $23(59.0)$ & \\
\hline
\end{tabular}

Clinical information: The comparison between study groups by certain clinical parameters of extraction showed that there were no significant differences $(\mathrm{P}>0.05)$ in all these parameters between the groups, as shown in table (3).

Table 3: Comparison between study groups by clinical parameters of extraction

\begin{tabular}{|c|c|c|c|c|c|c|}
\hline \multirow{2}{*}{$\begin{array}{l}\text { Clinical } \\
\text { Parameters }\end{array}$} & \multicolumn{3}{|c|}{ Study Groups } & \multirow{2}{*}{$\begin{array}{c}\text { Total (\%) } \\
n=39\end{array}$} & \multirow[b]{2}{*}{$X^{2}$} & \multirow[b]{2}{*}{ P-Value } \\
\hline & $\begin{array}{c}\text { Group A } \\
n=13\end{array}$ & $\begin{array}{c}\text { Group B } \\
n=13\end{array}$ & $\begin{array}{c}\text { Group C } \\
n=13\end{array}$ & & & \\
\hline \multicolumn{7}{|c|}{ Surgical time (Min.) } \\
\hline$<30$ & $4(33.3)$ & $5(41.7)$ & $3(25)$ & $12(30.8)$ & \multirow{2}{*}{0.722} & \multirow{2}{*}{0.907} \\
\hline$\geq 30$ & $9(33.3)$ & $8(29.6)$ & $10(37)$ & $27(69.2)$ & & \\
\hline \multicolumn{7}{|l|}{ Class } \\
\hline I & $6(31.6)$ & $8(42.1)$ & $5(26.3)$ & $19(48.7)$ & \multirow{2}{*}{1.43} & \multirow{2}{*}{0.615} \\
\hline II & $7(35.0)$ & $5(25.0)$ & $8(40.0)$ & $20(51.3)$ & & \\
\hline
\end{tabular}




\begin{tabular}{|c|c|c|c|c|c|c|}
\hline \multirow{2}{*}{$\begin{array}{l}\text { Clinical } \\
\text { Parameters }\end{array}$} & \multicolumn{3}{|c|}{ Study Groups } & \multirow{2}{*}{$\begin{array}{c}\text { Total }(\%) \\
n=39\end{array}$} & \multirow[b]{2}{*}{$X^{2}$} & \multirow[b]{2}{*}{ P- Value } \\
\hline & $\begin{array}{c}\text { Group A } \\
n=13\end{array}$ & $\begin{array}{c}\text { Group B } \\
n=13\end{array}$ & $\begin{array}{c}\text { Group C } \\
n=13\end{array}$ & & & \\
\hline \multicolumn{7}{|l|}{ Angulation } \\
\hline Disoangular & $2(50.0)$ & $1(25.0)$ & $1(25.0)$ & $4(10.3)$ & \multirow{4}{*}{1.13} & \multirow{4}{*}{0.979} \\
\hline Horizontal & $2(28.6)$ & $2(28.6)$ & $3(42.8)$ & 7 (17.9) & & \\
\hline Mesioangular & $6(30.0)$ & $7(35.0)$ & $7(35.0)$ & $20(51.3)$ & & \\
\hline Vertical & $3(37.5)$ & $3(37.5)$ & $2(25.0)$ & $8(20.5)$ & & \\
\hline \multicolumn{7}{|c|}{ Number of Roots } \\
\hline One & $6(33.3)$ & $5(27.8)$ & 7 (38.9) & $18(46.2)$ & \multirow{2}{*}{0.619} & \multirow{2}{*}{0.919} \\
\hline Two & $7(33.3)$ & $8(38.1)$ & $6(28.6)$ & $21(53.8)$ & & \\
\hline
\end{tabular}

Postoperative Pain: In comparison between the three groups by pain score for seven days, means of pain score in the $2^{\text {nd }}$ and $3^{\text {rd }}$ postoperative days were significantly lower in patients of group $A$ than that in group $\mathrm{B}$ and group $\mathrm{C}$ (5.9 versus 6.9 and 7.6, $\mathrm{P}=0.001$; and 4.6 versus 5.9 and $6.9, \mathrm{P}=0.001$, respectively). No statistically significant differences $(P>0.05)$ were found between the three groups regarding pain in the $1^{\text {st }}$ and from the $4^{\text {th }}$ to the $7^{\text {th }}$ postoperative days as shown in table (4).

Table 4: Comparison between study group by pain score for seven postoperative days

\begin{tabular}{|l|c|c|c|c|c|}
\hline \multirow{2}{*}{ Postoperative Pain } & \multicolumn{3}{|c|}{ Study Group } & \multirow{2}{*}{ P- Value } \\
\cline { 2 - 4 } & $\begin{array}{c}\text { Group A } \\
\text { Mean } \pm \text { SD }\end{array}$ & $\begin{array}{c}\text { Group B } \\
\text { Mean } \pm \text { SD }\end{array}$ & $\begin{array}{c}\text { Group C } \\
\text { Mean } \pm \text { SD }\end{array}$ & & \\
\hline Day One & $5.7 \pm 0.5$ & $6.3 \pm 1.03$ & $5.6 \pm 0.75$ & 2.20 & 0.125 \\
\hline Day Two & $5.9 \pm 1.03$ & $6.9 \pm 1.03$ & $7.6 \pm 0.86$ & 9.70 & 0.001 \\
\hline Day Three & $4.6 \pm 1.12$ & $5.9 \pm 0.95$ & $6.9 \pm 0.95$ & 16.97 & 0.001 \\
\hline Day Four & $3.6 \pm 0.85$ & $4.1 \pm 1.41$ & $4.5 \pm 0.87$ & 2.49 & 0.097 \\
\hline Day Five & $1.8 \pm 0.68$ & $2 \pm 0.81$ & $2.3 \pm 0.94$ & 1.05 & 0.358 \\
\hline Day Six & $0.84 \pm 0.80$ & $1.07 \pm 0.75$ & $0.84 \pm 0.80$ & 0.37 & 0.692 \\
\hline Day Seven & $0.46 \pm 0.51$ & $0.61 \pm 0.50$ & $0.53 \pm 0.66$ & 0.24 & 0.788 \\
\hline
\end{tabular}

\section{Follow Up: Mouth Opening}

Percentage of change between the groups: Percentage of change in mouth opening was compared between study group in the $1^{\text {st }}$ and $2^{\text {nd }}$ postoperative follow up, as shown in table (5). In the $1^{\text {st }}$ postoperative follow up, means of degree of mouth opening were significantly different between the three groups $(-12.9 \%$ in group $\mathrm{A},-14.5 \%$ in group $\mathrm{B}$, and $-24.5 \%$ in group $\mathrm{C}$, $\mathrm{P}=0.001)$.

No statistical significant difference between study groups $(\mathrm{P}=0.42)$ in the $2^{\text {nd }}$ follow up

Table 5: Comparisonin percentage of change in mouth opening between study groups in first and second follow up

\begin{tabular}{|l|c|c|c|c|c|}
\hline \multirow{2}{*}{$\begin{array}{l}\text { Change in Mouth } \\
\text { Opening (\%) }\end{array}$} & \multicolumn{3}{|c|}{ Study Groups } & \multirow{2}{*}{ F } & \multirow{2}{*}{ P- Value } \\
\cline { 2 - 6 } & $\begin{array}{c}\text { Group A } \\
\text { Mean } \pm \text { SD }\end{array}$ & $\begin{array}{c}\text { Group B } \\
\text { Mean } \pm \text { SD }\end{array}$ & $\begin{array}{c}\text { Group C } \\
\text { Mean } \pm \text { SD }\end{array}$ & \\
\hline $1^{\text {st }}$ follow up & $-12.9 \pm 3.10$ & $-14.5 \pm 4.65$ & $-24.5 \pm 4.98$ & 6.295 & 0.001 \\
\hline $2^{\text {nd }}$ follow up & $-2.7 \pm 3.34$ & $-1.5 \pm 1.84$ & $-1.99 \pm 1.56$ & 1.7 & 0.42 \\
\hline
\end{tabular}




\section{Swelling:}

Note: Facial swelling was performed by measuring the distance distance from corner of mouth to attachment of ear lobe (line A) the second line is the distance from outer canthus of eye to angle of mandible (line B).

Percentage of change in facial swelling was compared between study group in the $1^{\text {st }}$ and $2^{\text {nd }}$ postoperative follow up. In the $1^{\text {st }}$ postoperative follow up, means of degree of facial swelling were significantly different $(\mathrm{P}=0.002)$ between the three groups (in both line $\mathrm{A}$ and line $\mathrm{B})$.

No statistical significant difference between study groups $(\mathrm{P}=0.172 \& 0.561)$ in the $2^{\text {nd }}$ follow up, as shown in table (6).

Table 6: Comparison in change of line $B$ between study groups in $1^{\text {st }}$ and $2^{\text {nd }}$ follow up

\begin{tabular}{|c|c|c|c|c|c|}
\hline \multicolumn{6}{|c|}{ Follow up of line $A$} \\
\hline \multirow[b]{2}{*}{ Change in Line A (\%) } & \multicolumn{3}{|c|}{ Study Groups } & \multirow[b]{2}{*}{$\mathbf{F}$} & \multirow[b]{2}{*}{ P-Value } \\
\hline & $\begin{array}{c}\text { Group A } \\
\text { Mean } \pm \text { SD }\end{array}$ & $\begin{array}{c}\text { Group B } \\
\text { Mean } \pm \text { SD }\end{array}$ & $\begin{array}{c}\text { Group C } \\
\text { Mean } \pm \text { SD }\end{array}$ & & \\
\hline $1^{\text {st }}$ follow up & $7.34 \pm 3.27$ & $7.31 \pm 2.70$ & $12.52 \pm 5.51$ & 7.22 & 0.002 \\
\hline $2^{\text {nd }}$ follow up & $0.32 \pm 1.08$ & $0.32 \pm 0.67$ & $0.99 \pm 1.42$ & 1.85 & 0.172 \\
\hline \multicolumn{6}{|c|}{ Follow up of line B } \\
\hline \multirow[b]{2}{*}{ Change in Line B (\%) } & & Study Groups & & \multirow[b]{2}{*}{$\mathbf{F}$} & \multirow[b]{2}{*}{ P- Value } \\
\hline & $\begin{array}{c}\text { Group A } \\
\text { Mean } \pm \text { SD }\end{array}$ & $\begin{array}{c}\text { Group B } \\
\text { Mean } \pm \text { SD }\end{array}$ & $\begin{array}{c}\text { Group C } \\
\text { Mean } \pm \text { SD }\end{array}$ & & \\
\hline $1^{\text {st }}$ follow up & $7.21 \pm 4.24$ & $6.05 \pm 1.83$ & $12.14 \pm 5.11$ & 8.57 & 0.002 \\
\hline $2^{\text {nd }}$ follow up & $0.47 \pm 1.0$ & $0.71 \pm 1.14$ & $1.15 \pm 2.33$ & 0.588 & 0.561 \\
\hline
\end{tabular}

\section{Discussion}

There have been many surveys investigating the influence of administration of NSAIDs or glucocorticoid drugs on post-operative inflammation, but as a result of differences in inflammation assessment, prescriptive drugs, patterns of administration and provided dose, the comparison between the results is rather difficult. ${ }^{(9)}$

Age, sex between the three groups: Patients in the age range between (20-30) represent the highest percentage in this study which is in keeping with Breik and Grubor ${ }^{(10)}$, in 2008, Hashemipour et al. ${ }^{(11)}$, in 2013 who found that most patients in their study were in the third decade of life.

This may be related to the fact that problem associated with impactedthird molar started at the time of eruption that indicate their removal, as theprevalence of third molar impaction decreased with increasing age due toextraction of impacted teeth ${ }^{(12)}$.

The majority of patients in this study were between (20-30) and it corresponds with the studies mentioned earlier. and $56.4 \%$ was in age range $(\leq 25)$ and $43.6 \%$ $(>25)$ years.
The data of this study revealed that the percentage of femalepatient was (59\%) and the percentage of male patients was $(41 \%)$ and there wasno significant difference in distribution of males and females in study and control groups.

The higher occurrence in female may be the result of growth differencebetween male and female. Female growth usually stops with time of eruption ofthird molar, while in male jaws growth persists during third molar eruption,providing more space for eruption ${ }^{(13)}$.

Angulation, classification, favorability and no. of roots and side of impacted lower third molars.

In the present study, mesioangular impaction was the most common(51.3\%) followed by vertical (20.5\%), horizontal (17.9\%), and distoangular(10.3\%).

Mesioangular impactions may be the most common type and thisprobably due to their late development and maturation, path of eruption andlack of space in mandible at later age. This finding was reported by many otherstudies ${ }^{(14,15)}$. 
However, this result disagreed with the different studies $^{(16,17,18)}$ who reported the vertical angulation is the commonest one. This could be due to thefact that a different method of classifying angulation was used in these studies.

The findings of the present study were in agreement with a large numberof reports that show most impacted third molars were at Class II position,AlmendrosMarques et al., in $2006^{(17)}$ reported Class IIB as the most commonposition of mandibular third molar.

Duration of operation: There was no significant difference between study and placebo controlgroups regarding time of operation as p-value equal to 0.907 . Thismay be due to the type of impacted teeth where the teeth selected in sameposition, position $B$, and all the surgical operations were performed by the sameoperator. So the time of operation had no effect on the results of this study. AsPreviously suggested that there may be a close association between time ofoperation and postoperative morbidities ${ }^{(18)}$.

Pain and trismus: Numeric rating scale was utilized in this study to rate the intensity of painthat felt after surgical removal of the wisdom teeth, as it is easy to beunderstood by patient and does not need language translation. The data thathave been gained by VAS are interpreted and documented in simple manner andparametric tests can be used for analyzing its result ${ }^{(19)}$.

The results of this study showed that the highest level of pain for all three groups was seen in the 2nd day of operation, after that the pain scoretended to decline with time till the seventh day and a significant difference between the days within each group confirming that the maximumpain intensity occur within first $24 \mathrm{hrs}$ after operation. Since pain starts with thetermination of local anesthesia with peak level in (6-12) hrs after surgicaloperation (20), and it persists for about two to three days, thenits intensity gradually decreases till the 7 th postoperative day ${ }^{(21)}$, so in this study the pain was measured from the first day ofoperation throughout 7 days.

The results of this study also revealed the most significant decrease in pain scores in the Etoricoxib group followed by predisolone group then with placebo control group, that reached a significant level on the $2^{\text {nd }}$ and $3^{\text {rd }}$ day which was in favor of the etoricoxib followed by prednislone then the placebo control group, while it was non-significant in the 4 th, 5 th, $6^{\text {th }}$ and 7 th days between the placebo control and study groups, this may be due to analgesic effects of prednisolone and etoricoxib.

Limitation in mouth opening reaches its maximum intensity in the secondpostoperative day then the symptoms gradually improved and get better at theseventh postoperative day ${ }^{(22)}$, so in this study the trismus ismeasured at the 2 nd and 7 th postoperative days.

In this study: It was noticed that the significant reduction of the mouth opening ( $p$ value 0.001 ) was seen in placebo control group $(-24.5 \%)$ in the $1^{\text {st }}$ follow up appointment. The least reduction of the of mouth opening was seen in Etoricoxib (-12.9\%) followed by prednisolone group (-14.5\%).

There is was insignificant value between study and control groups in the $2^{\text {nd }}$ follow up ( $p$ vale 0.42 ).

The finding of this study is inconsistent with Carriches et al (23) who compared the efficacy of methylprednisolone (glucocorticoid) versus diclofenac (NSAID) upon inflammation and trismus after removal of impacted mandibular teeth. They did not find any significant difference between groups.

This study was comparatively consistent with Claseman et $\mathrm{al}^{(24)}$ assessed the analgesic efficacy of preemptive ketorolac and dexamethasone for third molar surgery. According to their results, the pain and the amount of having extra analgesics reported by patients receiving $8 \mathrm{mg}$ IV dexamethasone did not have significant difference with patients receiving $30 \mathrm{mg}$ IV Ketorolac. In this study, celecoxib had better effects on pain relief in $24 \mathrm{~h}$ after surgery; this difference may be related to different routes of drug administration.

Moore et al ${ }^{(25)}$ evaluated the effects of rofecoxib and dexamethasone on pain and trismus after third molar surgery. In their study, MMO of patients receiving dexamethasone had a reduction of $24.1 \%$ from the base limit while the rofecoxib group had $43.3 \%$. Reported pain did not show any significant differences and both groups had moderate pain perception. These differences may be contributed to the type of rescue dose given to patients which was $400 \mathrm{mg}$ ibuprofen. Ibuprofen is a NSAID type of drug and can add on anti-inflammatory response and effects of rofecoxib or dexamethasone.

Whereas Baxendale et al. ${ }^{(26)}$ observed the 
elimination of analgesic intake by administering preoperative dexamethasone while trismus was not affected.

This effect can be related to the role of prostaglandins in local pain and their inhibition by NSAIDs will result in pain relief. Glucocorticoids are effective in each step of inflammation process and subsequent decrease in capillary dilation, circulating lymphocytes, fibroblast proliferation and prostaglandin and leukotriene inhibition. Most single dose glucocorticoid drugs used in oral surgeries are not effective for more than $24 \mathrm{~h}$, so for maintaining their anti-inflammatory effects they should be taken for a minimum of 3 and maximum of 5 days for gaining the maximum efficiency and minimum risk of delayed healing and suppression of HPA axis ${ }^{(27)}$.

Swelling: Facial measurement was performed by measuring the distance distance from corner of mouth to attachment of ear lobe (line A) the second line is the distance from outer canthus of eye to angle of mandible (line B) Preoperative measurement was used as baseline record as of Amin and Laskin methodology ${ }^{(28)}$.

In this study the effect of study drugs showed significant difference in A and B lines of inflammation in comparison with placebo control group in the 1st follow up ( $p$ value 0.002 ). However there was insignificant difference in the $2^{\text {nd }}$ follow up between study and control groups.

The significance was in favor of prednisolone 10 $\mathrm{mg}$ as in compare with placebo control group. However, there was slight difference between the study groups but it was insignificant.

Costa et al. (29) analyzed the preemptive effect of etoricoxib (120 mg) and placebo on inflammatory events after the removal of third molars and found no significant difference in facial measurements between groups at any evaluation time.

Sotto-Maior etal. ${ }^{(30)}$ compared the anti-inflammatory effects of etoricoxib (120 mg) and dexamethasone (4 $\mathrm{mg}$ ) administered orally one hour prior to the procedure and found no significant differences in postoperative swelling.

Mojsa et al. ${ }^{(31)}$ evaluated the submucosal injection of dexamethasone and found that peak swelling in patients who received placebo occurred on the third day and these patients had significantly larger facial measurements.
Antunes et al. (32) compared the administration of dexamethasone intramuscularly (masseter muscle), orally and a placebo and found that the control group had the greatest swelling.

\section{Conclusions}

1. Etoricoxib $120 \mathrm{mg}$ showed a significant effect on reduction of pain following surgical removal of impacted $3^{\text {rd }}$ molar.

2. Etoricoxib $120 \mathrm{mg}$ showed a significant effect on reduction of trismus following surgical removal of impacted $3^{\text {rd }}$ molar.

3. Prednisolone $10 \mathrm{mg}$ showed a significant effect on reduction of facial swelling following removal of impacted $3^{\text {rd }}$ molar as in compare with other two groups, however the result showed no significant difference as in compare with Etoricoxib $120 \mathrm{mg}$.

4. The effect of etoricoxib was significant in the shortterm effect (48hrs) and was insignificant in one week follow ups in comparison with placebo control group.

Acknowledgment: The study was self-funded.

Conflicts of interest: None of the authors have any competing interests in the manuscript.

Ethical Clearance: This research has exemption as it a routine treatment (no new materials were used).

\section{References}

1. Sands T, Pynn BR, Nenniger S. Third molar surgery: current concepts and controversies. Part 1. Oral Health. 1993 May;83(5):11-4.

2. Fonseca RJ. Oral and maxillofacial surgery, vols 1, 2, 1st edn. Saunders, Philadelphia. 2000; pp 122, 256-260

3. Calvo AM, Sakai VT, Modena KC, Colombini BL, Gallina MC, Dionisio TJ, Lauris JR, Santos $\mathrm{CF}$. Comparison of the efficacy of etoricoxib and ibuprofen in pain and trismus control after lower third molar removal. Rev Odontol UNICID. 2006 Jan;18(1):29-36.

4. Hupp JR. Contemporary Oral and Maxillofacial Surgery: Pageburst Retail. Elsevier Mosby; 2008.

5. Kim K, Brar P, Jakubowski J, Kaltman S, Lopez E. The use of corticosteroids and nonsteroidal antiinflammatory medication for the management 
of pain and inflammation after third molar surgery: a review of the literature. Oral Surgery, Oral Medicine, Oral Pathology, Oral Radiology, and Endodontology. 2009 May 1;107(5):630-40.

6. Gage T, Pickett F. Mosby's dental drug reference, 5th edn. Elsevier Mosby, St. Louis. 2001; pp 122, 551

7. Olsen AM, Fosbøl EL, Lindhardsen J, Andersson C, Folke F, Nielsen MB, Køber L, Hansen PR, Torp-Pedersen C, Gislason GH. Cause-specific cardiovascular risk associated with nonsteroidal anti-inflammatory drugs among myocardial infarction patients-a nationwide study. PloS one. 2013 Jan 30;8(1):e54309.

8. Wenner MM, Edwards DG, Ray CA, Rose WC, Gardner TJ, Stillabower M, Farquhar WB. Celecoxib does not alter cardiovascular and renal function during dietary salt loading. Clinical and Experimental Pharmacology and Physiology. 2011 Aug;38(8):543-9.

9. Moghaddamnia AA, Nosrati K, Mehdizadeh M, Milani S, Aghvami M. A comparative study of the effect of prednisolone and celecoxib on MMO (maximum mouth opening) and pain following removal of impacted mandibular third molars. Journal of maxillofacial and oral surgery. 2013 Jun 1;12(2):184-7.

10. Breik $\mathrm{O}$, Grubor D. The incidence of mandibular third molar impactions in different skeletal face types. Australian dental journal. 2008 Dec;53(4):320-4.

11. Hashemipour MA, Tahmasbi-Arashlow M, FahimiHanzaei F. Incidence of impacted mandibular and maxillary third molars: a radiographic study in a Southeast Iran population. Medicina oral, patologia oral y cirugia bucal. 2013 Jan; 18(1):e140.

12. Hugoson A. The prevalence of third molars in a Swedish population: an epidemiological study. Community Dent Health. 1988;5:121-38.

13. Bishara SE, Ortho D. Impacted maxillary canines: a review. American Journal of Orthodontics and Dentofacial Orthopedics. 1992 Feb 1;101(2):15971.

14. Byahatti S, Ingafou MS. Prevalence of eruption status of third molars in Libyan students. Dental Research Journal. 2012 Mar;9(2):152.

15. Hassan AH. Pattern of third molar impaction in a Saudi population. Clinical, cosmetic and investigational dentistry. 2010;2:109.

16. Bataineh AB, Albashaireh ZS, Hazza'a AM. The surgical removal of mandibular third molars: A study in decision making. Quintessence international. 2002 Sep 1;33(8).

17. Almendros-Marqués N, Berini-Aytés L, GayEscoda C. Influence of lower third molar position on the incidence of preoperative complications. Oral Surgery, Oral Medicine, Oral Pathology, Oral Radiology, and Endodontology. 2006 Dec 1;102(6):725-32.

18. Oikarinen K. Postoperative pain after mandibular third-molar surgery. Acta Odontologica Scandinavica. 1991 Jan 1;49(1):7-13.

19. Thomas SH, editor. Emergency Department Analgesia: An Evidence-Based Guide. Cambridge University Press; 2008 Sep 25.

20. Haraji A, Rakhshan V. Chlorhexidine gel and less difficult surgeries might reduce post-operative pain, controlling for dry socket, infection and analgesic consumption: a split-mouth controlled randomised clinical trial. Journal of oral rehabilitation. 2015 Mar;42(3):209-19.

21. Marković AB, Todorović L. Postoperative analgesia after lower third molar surgery: contribution of the use of long-acting local anesthetics, lowpower laser, and diclofenac. Oral Surgery, Oral Medicine, Oral Pathology, Oral Radiology, and Endodontology. 2006 Nov 1;102(5):e4-8.

22. White Jr RP, Shugars DA, Shafer DM, Laskin DM, Buckley MJ, Phillips C. Recovery after third molar surgery: clinical and health-related quality of life outcomes. Journal of oral and maxillofacial surgery. 2003 May 1;61(5):535-44.

23. Carriches CL, González JM, Rodríguez MD. The use of methylprednisolone versus diclofenac in the treatment of inflammation and trismus after surgical removal of lower third molars. Medicina oral, patología oral y cirugía bucal. Ed. inglesa. 2006;11(5):12.

24. Claseman TS, Foley WL, Davis RD, Morrison JW, Palmore CA, Murchison DF. A clinical evaluation of the analgesic efficacy of preoperative administration of ketorolac and dexamethasone following surgical removal of third molars. Anesthesia progress. 1998;45(3):110.

25. Moore PA, Brar P, Smiga ER, Costello BJ. Preemptive rofecoxib and dexamethasone for 
prevention of pain and trismus following third molar surgery. Oral Surgery, Oral Medicine, Oral Pathology, Oral Radiology, and Endodontology. 2005 Feb 1;99(2):E1-7.

26. Baxendale BR, Vater $M$, Lavery KM. Dexamethasone reduces pain and swelling following extraction of third molar teeth. Anaesthesia. 1993 Nov;48(11):961-4.

27. Hyrkäs T, Ylipaavalniemi P, Oikarinen VJ, Paakkari I. A comparison of diclofenac with and without single-dose intravenous steroid to prevent postoperative pain after third molar removal. Journal of oral and maxillofacial surgery. 1993 Jun 1;51(6):634-6.

28. Amin MM, Laskin DM. Prophylactic use of indomethacin for prevention of postsurgical complications after removal of impacted third molars. Oral surgery, oral medicine, oral pathology. 1983 May 1;55(5):448-51.

29. Costa FW, Soares EC, Esses DF, Silva PD, Bezerra TP, Scarparo HC, Ribeiro TR, Fonteles CS. A splitmouth, randomized, triple-blind, placebo-controlled study to analyze the pre-emptive effect of etoricoxib $120 \mathrm{mg}$ on inflammatory events following removal of unerupted mandibular third molars. International Journal of Oral and Maxillofacial Surgery. 2015 Sep 1;44(9):1166-74.

30. Sotto-Maior BS, Senna PM, Assis NM. Corticosteroids or cyclooxygenase 2-selective inhibitor medication for the management of pain and swelling after third-molar surgery. Journal of Craniofacial Surgery. 2011 Mar 1;22(2):758-62.

31. MojsaIM,PokrowieckiR,LipczynskiK, Czerwonka D, Szczeklik K, Zaleska M. Effect of submucosal dexamethasone injection on postoperative pain, oedema, and trismus following mandibular third molar surgery: a prospective, randomized, doubleblind clinical trial. International journal of oral and maxillofacial surgery. 2017 Apr 1;46(4):524-30.

32. Antunes AA, Avelar RL, Martins Neto EC, Frota $R$, Dias E. Effect of two routes of administration of dexamethasone on pain, edema, and trismus in impacted lower third molar surgery. Oral Maxillofac Surg 2011;15:217-23. 